\title{
Paljon melua tyhjästä vai uusi koulutuskäsitys?
}

\begin{abstract}
ワyössä oppiminen on noussut viime vuosina keskeiseksi aiheeksi koulutus- ja oppimisjärjestelyistä puhuttaessa. Syitä on monia. Oppilaitoskeskeinen koulutus on ollut hidas reagoimaan nopeasti muuttuviin työelämän tarpeisiin. Teorian ja käytännön on sanottu kulkevan liian erillään toisistaan. Monia laitteita ja koneita on mahdoton hankkia pelkästään koulun tarpeisiin. Kukaan ei vakavissaan vaadi, että ammattiopistolla pitää olla oma paperikone. Kouluoppiminen on siirtynyt puutteellisesti osaamiseksi työpaikoilla. Työn ja koulun maailmojen on väitetty sijaitsevan liian kaukana toisistaan. Totta onkin, että oppilaitoksen piilo-opetussuunnitelmaan sisältyvän hiljaisen tiedon hallinta ei riitä työpaikoille syntyvien toimijayhteisöjen hiljaisen tiedon hallintaan. Perinteinen oppilaitos ja nykyaikainen työpaikka ovat erilaisia oppimisympäristöinä. Koulussa tehdään asioita yksin, ainakin suoritukset arvioidaan yksilön tekoina. Siellä simuloidaan ongelmia, eletään mielikuvien varassa eikä luoda juurikaan uutta. Koulussa eletään symbolien maailmassa ja näiden symbolien käyttötaidot ovat keskeinen oppimisen kohde. Institutionaalinen koulutus on aina uskonut yleistävään oppimiseen, siihen, että formaaliset tiedot ja taidot muuntuvat tarvittaessa konkreettisiksi työtehtävien hallinnaksi.
\end{abstract}

I hminen oppii tekemällä ja toimimalla, tarkkailemalla ja vuorovaikutuksessa toisten toimijoiden ja ympäristönsä kanssa. Aito tuottavan työn ympäristö täyttää monien oppimisteorioiden korostamat tehokkaan oppimisen edellytykset: kokemuksellisuuden, yhteisöllisyyden, ongelmanratkaisun, mielekkyyden, tilannekohtaisuuden jne. Työssä oppiminen helpottaa työmarkkinataitojen oppimista ja sekä työhön että työyhteisöön sosiaalistumista. Työorganisaatio on usein myös koulua useammin sitein ympäristöönsä kiinnittynyt. Mutta työssä oppiminen on myös konservatiivinen ja säilyttävä oppimisen muoto. Työssä ei voi oppia muuta kuin sen, mitä työpaikalla tehdään. Harjoitteluaika tarjoaa vain näytteen kaikista myöhemmin eteen tulevista ongelmista ja tehtävistä. Aloittelijan on vaikea tehdä päätelmiä ilmiöiden kausaalisista tai funktionaalisista suhteista. Ilman opastusta hän ei näe, mikä on tärkeätä ja mikä vähemmän tärkeää. Työssä oppimisen kokemukset onkin nostettava tietoisen ja teoreettisen pohdinnan kohteeksi. Kokemusta on laajennettava ja se on käsitteellistettävä. Siihen tarvitaan formaalista ja käsitteellistä opiskelua.

$\mathrm{T}$

yössä oppimisen tehostaminen ei merkitse vain työharjoittelun pidentämistä. Työ ja työpaikka on opinnollistettava, ohjaajat koulutettava ja työnantajan on 
otettava osavastuu myös perusosaamisen tuottamisesta. Tutkijoilta odotetaan relevantteja avauksia pedagogisten ja didaktisten ongelmien helpottamiseksi, oppilaitoksilta ja työorganisaatioilta uudenlaista kumppanuutta. Selvää on, että työssä oppimisen järjestelmää ei voida autoritaarisesti ja ulkoa pakottaa työelämän käytännöksi. Työnantajan on koettava aitoa myös tässä innovaatiossa.

$\mathrm{U}$ uden vuosituhannen ensimmäisen vuoden viimeinen Aikuiskasvatuksen numero on valinnut teemakseen työssä oppimisen. Lehti tarjoaa näin aineksia tärkeälle keskustelulle ja viitteitä jatkotutkimukselle. Johdantoartikkelina teemaan toimii Reijo Miettisen kriittinen ja analyyttinen pohdiskelu konstruktivismista, erityisesti konstruktivistisesta oppimiskäsityksestä, jolla työssä oppimista - niin kuin lähes kaikkea muutakin - on perusteltu. Arvokkaana pidän myös, että työmarkkinaosapuolten edustajat kommentoivat teemaamme. Yhtä asiaa valitan. Termistö on niin vakiintumatonta, että lukijalle ei ole voitu laatia "sanakirjaa" lukemisen helpottamiseksi. Opetushallinto näyttää varanneen työssäoppimisen, yhteenkirjoitettuna, keskiasteen työharjoittelun yhteyteen, ja erikseen kirjoitettuna termi näin viittaisi yleiseen kattokäsitteeseen, mutta tutkijat eivät aina eroa yhteen ja erikseen kirjoittamisen välillä tee. Käytettyjä termejä ovat myös työperusteinen oppiminen, työstä oppiminen, työhön oppiminen, työpaikalla oppiminen, tehtäväoppiminen, ja jopa oppisopimuskoulutuksella joskus viitataan käsitteeseen. Näyttötutkintojen ja näyttöjen tematiikka liittyy myös aiheeseen. Aika varmasti siivoaa käsitevaraston.

Ooska tämä on viimeinen pääkirjoitukseni lehden päätoimittajana, kii\än lukijoita ja kirjoittajia menneestä kolmesta vuodesta. Se, että lehteä luetaan, näkyy tutkijoiden tekemien lähdeviittausten määrässä. Aikuiskasvatuksen kentällä toimivien mielipide jää helpommin piiloon. Toivonkin, että he aktiivisesti ottaisivat lehden tekijöihin, toimituskuntaan, päätoimittajaan tai toimitussihteeriin, yhteyttä keskustelun synnyttämiseksi ja ylläpitämiseksi.

Reijo Raivola 